\title{
Body mass and acquisition of breeding plumage of wintering Calidris pusilla (Linnaeus) (Aves, Scolopacidae) in the coast of Pernambuco, north-eastern Brazil
}

\author{
Carmem E. Fedrizzi ${ }^{1}$, Severino M. de Azevedo Júnior ${ }^{2,3} \&$ Maria E. Lacerda de Larrazábal ${ }^{2}$ \\ 1 Programa de Pós Graduação em Oceanografia Biológica, Departamento de Oceanografia, Fundação Universidade Federal \\ do Rio Grande. Avenida Itália Km 8, Carreiros, Caixa Postal 474, 96201-900 Rio Grande-Rio Grande do Sul, Brasil. \\ E-mail: cefedrizzi@uol.com.br \\ 2 Departamento de Zoologia, Universidade Federal de Pernambuco. Avenida Professor Moraes Rego 1235, Cidade \\ Universitária, 50670-420 Recife, Pernambuco,Brasil.E-mail: mells@ufpe.br, smaj@ufpe.br \\ ${ }_{3}^{3}$ Departamento de Biologia, Universidade Federal Rural de Pernambuco. Rua Dom Manuel de Medeiros, Dois Irmãos, \\ 52171-900 Recife, Pernambuco, Brasil.
}

\begin{abstract}
Annually, large flocks of semipalmated sandpiper Calidris pusilla (Linnaeus, 1766) winter along South America coast, between September-April. They store fats in order to moult and return to their breeding grounds. Here, was examined body masses and plumage of adults Semipalmated Sandpipers during the departure month to evaluate the relationship between body mass and plumage. Fieldwork was conducted at Coroa do Avião ( $\left.7^{\circ} 40^{\prime} \mathrm{S}, 34^{\circ} 50^{\prime} \mathrm{W}\right)$, Pernambuco. Birds were trapped in mist-nets between April 1990 and 1997. They were weighed, and aged according to plumage. Adult plumage may be (1) non-breeding, (2) pre-breeding, and (3) breeding. A total of 213 birds were weighed and examined, so that $8.0 \%$ (17) presented non-breeding plumage, 54.0\% (115) pre-breeding, and $38.0 \%(81)$ breeding plumage. As in Semipalmated Sandpiper, $25 \mathrm{~g}$ is the minimum body mass required to migrate, birds with breeding plumage and most with pre-breeding, were potentially apt to migrate. Non-breeding plumage birds presented smaller body mass. Apparently physiological problems and infestation may be important factors to explain over-summering, i.e., individuals remaining in the wintering grounds during the boreal summer.

KEY WORDS. Migration, over-summering, shorebirds, South America, wintering areas.
\end{abstract}

RESUMO. Anualmente grandes bandos de Calidris pusilla (Linnaeus, 1766) invernam ao longo da costa da América do Sul, entre setembro e abril. Estas aves acumulam gordura para realizar mudas e retornar aos seus locais de reprodução. Neste estudo foram examinadas a massa corpórea e a plumagem de $C$. pusilla adultos durante o mês de retorno aos sítios reprodutivos, de forma a avaliar sua relação. A amostragem foi conduzida na Coroa do Avião (740’S, 3450’W), Pernambuco. As aves foram capturadas com redes de neblina entre abril de 1990 e 1997. Os adultos e os jovens foram diferenciados através da análise de plumagem. A plumagem dos adultos foi classificada em: (1) não-reprodutiva, (2) pré-reprodutiva e (3) reprodutiva. Um total de 213 aves foi examinado e sua massa corpórea mensurada. Destas, $8.0 \%$ (17) apresentaram plumagem não-reprodutiva, $54.0 \%$ (115) préreprodutiva e $38.0 \%$ (81) reprodutiva. Sendo $25 \mathrm{~g}$ a massa corpórea mínima necessária para a migração em C. pusilla, as aves em plumagem reprodutiva e a maior parte daquelas com plumagem pré-reprodutiva estavam potencialmente aptas a migrar. As aves em plumagem não-reprodutiva apresentaram as menores massas corpóreas. Aparentemente, problemas fisiológicos e parasitários podem ser importantes fatores para explicar a permanência de adultos nos locais de invernada durante o verão boreal.

PALAVRAS CHAVE. América do Sul, áreas de invernada, aves limícolas, migração.

The Semipalmated Sandpiper Calidris pusilla (Linnaeus, 1766) is a small (13-15 cm, 15-36g) shorebird that breeds near the water in low sub-arctic tundra of New World (from Alaskan coast along Canada to northern Quebec) (Gratto-Trevor 1992, Piersma et al. 1996). The sexes are similar in plumage, but females are slightly larger, especially in bill length (HAYMAn et al. 1986). This monotypic species presents three non-nominated breeding populations, so that Western population present longer bill and wing lengths on average (HARRINGTON \& MORRISON 1979, MoRRISON 1984, Hayman et al. 1986, Gratto-Trevor 1992, Piersma et al. 1996). 
With the approaching of the boreal winter, birds from the eastern Artic migrate southward, to reaching their wintering grounds in the Central and South America Atlantic coast (e.g. Harrington \& Morrison 1979, Morrison 1984, Morrison \& Ross 1989). Several researches (e.g. McNeil \& Cadieux 1972) emphasized the importance of fat stored to the migration. Such reserves provide energy to non-stop flights of 3,000 to 4,000 kilometres (Gratto-Trevor 1992).

Annually, between the middle of August and the early September, flocks of Semipalmated Sandpiper arrive to the coast of the state of Pernambuco, north-eastern Brazil, staying there until April (AzEvEDo JúNIOR 1998). Studies on the morphometry and recovery of banded birds confirm that Eastern North America birds wintering in this region (AzEvedo JúNIOR \& LarrazÁbal 1999, AzeVEdo JúnIor et al. 2001). Here we present eight years data on the body mass of adults Semipalmated Sandpiper trapped in April, the departure period. As body condition may explain bird ability to migrate (ANTAS \& NASCIMENTO 1990), our aim was to evaluate the relationship between breeding plumage and body mass just after the northward migration.

\section{MATERIAL AND METHODS}

Fieldwork was carried out at the Coroa do Avião $\left(7^{\circ} 40^{\prime} \mathrm{S}\right.$ and $34^{\circ} 50^{\prime} \mathrm{W}$ ), a c. 2 ha islet during high tides, located on the north of the Canal de Santa Cruz estuarine complex, district of Igarassu, state of Pernambuco. The vegetation in the islet is restinga and the introduced palm Cocos nucifera Linnaeus (AZEVEDO JÚNIOR \& LARRAZÁBAL 1994). The eastern part of the area presents sandbanks that are utilized by several species of Neartic shorebirds (AzEvEDo JúNIOR 1998).

Semipalmated Sandpipers were trapped in mist-nets during nocturnal high tides, of a shorebird banding program carried out from April 1990-1997. The captures took place in April because it is the departure month of wintering shorebirds in the coast of Pernambuco (AzEvedo JúNIor et al. 2002). Captured birds were weighed with spring scales to the nearest $0.5 \mathrm{~g}$. Age was determined by plumage analysis, and each adult was classified according plumage categories (after HAYMAN et al. 1986): (1) non-breeding, rather plain grey-brown above; (2) pre-breeding, upper parts are mostly brownish-grey; and (3) breeding, upper parts generally greyish or buff, never with extensive rufous, dark centres to scapulars contrast strongly, and breast and fore-flanks streaked blackish.

Analysis of variance (ANOVA) was used to compare body masses among plumage categories. If significant differences were found, then was used Tukey's test (ZAR 1999) in order to identify significant differences among categories. Statistical analyses were performed using Statistica 5.0 (StatSoft, Inc.) software package. Significance level was set at $\mathrm{p}<0.05$.

\section{RESULTS}

A total of 213 adults were examined and weighed. Of these, $8.0 \%$ (17) presented non-breeding plumage, 54.0\% (115) pre-breeding, and 38.0 (81) breeding (Tab. I). Bird body mass was significantly different according to plumage $(\mathrm{F}=29.492$, d.f. $=2, p<0.001$ ), so that the three categories were unequal: non-breeding and pre-breeding $(\mathrm{p}<0.001)$, non-breeding and breeding $(\mathrm{p}<0.001)$, and pre-breeding and breeding $(\mathrm{p}<0.005)$.

Table I. Body masses of Semipalmated Sandpiper Calidris pusilla captured in April 1990-97 at Coroa do Avião. First row, mean and standard deviation in parenthesis; second row, range; and third row, the sample size.

\begin{tabular}{ccc}
\hline Non-breeding & Pre-breeding & Breeding \\
\hline $26.3(3.0)$ & $33.3(4.9)$ & $35.38(3.8)$ \\
$22.0-35.0$ & $21.0-46.0$ & $25.0-44.0$ \\
$\mathrm{n}=17$ & $\mathrm{n}=115$ & $\mathrm{n}=81$ \\
\hline
\end{tabular}

\section{DISCUSSION}

The body fat and flight range of some Charadriiforms can be estimated using the equations of McNeIL \& Cadieux (1972), which include as parameters the fresh weight and wing length. According to these equations, AnTAS \& NASCIMENTO (1990) stated that for Semipalmated Sandpiper the minimum body mass required to migrate was $25 \mathrm{~g}$. In this study, all individuals with breeding plumage presented body masses higher than $25 \mathrm{~g}$, and thus were potentially apt to migrate. However, only a smaller population of trapped birds had breeding plumage. This fact was expected since April is the month of returning of wintering shorebirds in the coast of Pernambuco. Furthermore, in the study area, Semipalmated Sandpiper reach its highest flight ranges in April and earlier May (AzEvEDo JúNIOR et al. 2002). This supports that these months correspond to the migration period in the region.

The breeding plumage can also be acquired in areas near the artic, during the migration (ANTAS \& NASCIMENTO 1990). This may explain the fact that most birds presented pre-breeding plumage. In this category, we found the extremes of body mass. This large amplitude of values includes individuals both apt and inapt to migrate (less than $25 \mathrm{~g}$ for the later). In the study area AZEVEDo JúNIOR \& LARRAZÁbAL (1999) reported the occurrence of contour moult throughout the year, and individuals with pre-breeding plumage occurring from March.

The highest flight range of Semipalmated Sandpiper at the Coroa do Avião was 3,547.77 kilometres for an individual trapped in April 1994, with $44 \mathrm{~g}$, wing length of $100 \mathrm{~mm}$, and pre-breeding plumage (AZEvEDo JÚNIOR et al. 2002). Furthermore, the highest flight ranges of Semipalmated Sandpiper in Pernambuco were found in individuals with pre-breeding plumage (AzEvedo Júnior et al. 2002). A research conducted in the State of Rio Grande do Sul, southern Brazil (LARA-RESENDE et al. 1989), found that in April, the mean body mass of Semipalmated Sandpiper was $33.2 \mathrm{~g}$ (range 23-40 g), and the flight

Revista Brasileira de Zoologia 21 (2): 249-252, junho 2004 
range for the highest mass values was $4,000 \mathrm{~km}$. In the state of Maranhão, northern Brazil, RodRIGUEs (2000), found a flight range varying between 2,000 and $2,800 \mathrm{~km}$, and a mean body mass for earlier May of 33.4 g (range 30-39 g).

Birds with non-breeding plumage had smaller body mass, and only a minor proportion of them were potentially apt to migrate. They may correspond to individuals without physiological conditions to moult and migrate. We could list three hypotheses to explain this: (1) these individuals may delay their departure, acquiring sufficient energetic reserves; (2) they can migrate, stopping at several points along their routes to replenish their reserves; and (3) they do not migrate to their breeding ground.

Some juvenile, sub-adults, and even moulting adults individuals are observed between May and July at the Coroa do Avião (AzEvedo JúnIor 1998). According to GratTo-Trevor (1992), most juveniles of Semipalmated Sandpiper stay in their wintering ground during the boreal summer. However, the permanence of adults in the wintering grounds during the boreal summer (over-summering) is probably related to physiological or parasitism problems, which prevent moulting and fattening (McNeIL et al. 1994). Studies with the Greater Yellowlegs Tringa melanoleuca (Gmelin, 1789) at wintering grounds in Venezuela (McNeIL et al. 1995, 1996) showed that there is an exponential decreasing of fat in relation to the infestation level by Trematode. High infestation level can prevent or delay the pre-migratory moult and fattening in some of these birds at their wintering grounds, being an important factor to the oversummering (McNeIl et al. 1996).

Another factor that could influence the migration are the environmental conditions. BUTLER et al. (1997) used some of the current models of flight energetic demand (e.g. CASTRO \& Myers 1988) and migration phenology to evaluate the role of wind assistance in the northward migration of the Western Sandpiper Calidris mauri (Cabanis, 1857). The authors stated that the frequency and duration of favourable winds are important to the migratory strategies of several species that undertake longdistance migrations at high altitudes, influencing their permanence in the wintering grounds, and also the flight speed and energetic demand (BUTLER et al. 1997). Thus, favourable winds could decrease the flight energetic demand, and thus some individuals with low body mass could also migrate.

Concluding, the highest values of body mass was found in birds with breeding plumage, which potentially were apt to migrate. Although the body mass of birds with pre-breeding plumage presented smaller mean values, they were also apt to migrate. Individuals that present non-breeding plumage in April probably correspond to adults over-summering in the area due physiological and infestation problems.

\section{ACKNOWLEDGMENTS}

We thank the Universidade Federal de Pernambuco, Universidade Federal Rural de Pernambuco, and Centro de
Pesquisas para a Conservação das Aves Silvestres (CEMAVE) for supporting this research. C.J. Carlos, J.P. Coimbra, M.M. Dias Filho, and an anonymous referee kindly reviewed and improved the manuscript. C.E. Fedrizzi received a master's scholarship of the Coordenação de Aperfeiçoamento de Pessoal de Nível Superior (CAPES).

\section{REFERENCES}

Antas, P.T.Z. \& I.L.S. Nascimento. 1990. Análise de dados de anilhamento de Calidris pusilla no Brasil, p. 6-19. In: S.M. Azevedo Júnior (Ed.). Anais do IV encontro nacional de anilhadores de aves. Recife, Universidade Federal Rural de Pernambuco, 151p.

Azevedo Júnior, S.M. 1998. As aves do Canal de Santa Cruz, Pernambuco, Brasil. Cadernos Ômega da Universidade Federal Rural de Pernambuco, Série Biologia, Recife, 5: 3550 .

Azevedo Júnior, S.M. \& M.E. Larrazábal. 1994. Censo de aves limícolas na Coroa do Avião, Pernambuco, Brasil, informações de 1991 a 1992. Revista Nordestina de Zoologia, Recife, 1 (1): 236-277.

1999. Captura e Anilhamento de Calidris pusilla (Scolopacidae) na Costa de Pernambuco. Ararajuba, Brasília, 7 (2): 63-69.

Azevedo Júnior, S.M.; M.M. Dias Filho; M.E.L. Larrazábal; W.R. Telino Júnior; R.M. Lyra-Neves \& C.J.G. Fernandes. 2001. Recapturas e recuperações de aves migratórias no litoral de Pernambuco, Brasil. Ararajuba, Brasília, 9 (1): 33-42.

Azevedo JúNior, S.M.; M.M. Dias Filho; M.E.L. LarrazÁbal \& C.J.G. Fernandes. 2002. Capacidade de vôo de quatro espécies de Charadriiformes (Aves) capturadas em Pernambuco, Brasil. Revista Brasileira de Zoologia, Curitiba, 19 (Supl.1): 183-189.

Butler, R.W.; T.D. Williams; N. Warnock \& M.A. Bishop. 1997. Wind assistance: a requirement for migration of shorebirds? Auk, Lawrence, 114 (3): 456-466.

Castro, G. \& J.P. Myers. 1988. A statistical method to estimate the cost of flight in birds. Journal of Field Ornithology, Tulsa, 59: 369- 380

Gratto-Trevor, C.L. 1992. Semipalmated Sandpiper. In: A. Pool; P. Stettenheim \& F. Gill. (Eds). The Birds of North America. \# 6. Washington, DC, The Academy of Natural Sciences and The American Ornithologists' Union, 20p.

HaRrington, B.A. \& R.I. MoRrison. 1979. Semipalmated Sandpiper migration in North America, p. 83-100. In: F.A. PitelKA (Ed.) Shorebirds in marine environments (Studies in Avian Biology No. 2). Camarillo, Cooper Ornithological Society, $\mathrm{VII}+259 \mathrm{p}$.

Hayman, P.; J. Marchant \& T. Prater 1986. Shorebirds, an identification guide to the waders of the world. Boston, Houghton Mifflin Company, 412p.

Lara-Resende, S.; F. Leeuwenberg \& B.A. Harrington. 1989. Biometrics of Semipalmated Sandpipers Calidris pusilla in Southern Brazil. Wader Study Group Bulletin, Tring, 55: 25-26.

Revista Brasileira de Zoologia 21 (2): 249-252, junho 2004 
McNeil R. \& F. Cadieux 1972. Numerical formulae to estimate flight range of some North American shorebirds from fresh weight and length. Bird Banding, Tulsa, 43 (2): 107-113.

McNeil R.; M.T. Díaz \& A. Villeneuve. 1994. The mystery of shorebird over-summering: a new hypothesis. Ardea, Groningen, 82: 143-152.

McNeil R.; M.T. Díaz; B. Casanova \& A. Villeneuve. 1995. Trematode parasitism as a possible factor in over-summering of greater yellowlegs (Tringa melanoleuca). Ornitologia Neotropical, Athens, 6 (2): 57-65.

McNeil R., M.T. Díaz, B. Casanova, A. Villeneuve \& M. Thibault. 1996. Trematode infestation as a factor in shorebird oversummering: a case study of the greater yellowlegs (Tringa melanoleuca). Bulletin of Scandinavian Society of Parasitology, Stockholm, 6 (2): 114-117.

Morrison, R.I.G. 1984. Migration systems of some new world shorebirds, p. 125-202. In: J. Burguer \& B.L. Olla (Eds). Shorebirds: migration and foraging behavior. Behavior of marine animals. New York, Plenum Press, vol. 6, 344p.

Morrison, R.I.G. \& R.K. Ross. 1989. Atlas of Neartic shorebirds on the coast of South America. Ottawa, Canadian Wildlife Service, vol. 2, 325p.

Piersma T.; J. Van Gils \& P. Wiersma. 1996. Family Scolopacidae (Sandpipers, Snipes and Phalaropes), p. 444-533. In: J. DEL Hoyo; A. Elliott \& J. Sargatal (Eds). Handbook of the birds of the World. Hoatzin to Auks. Barcelona, Linx Edicions, vol. 3, 821p.

Rodrigues, A.A.F. 2000. Seasonal abundance of Neartic shorebirds in the gulf of Maranhão, Brazil. Journal of Field Ornithology, Tulsa, 71 (4): 665-675.

ZAR, J.H. 1999. Biostatistical analysis. New Jersey, Prentice Hall, $4^{\text {th }}$ ed., XII+911p.

Received in 01.X.2003; accepted in 14.V.2004. 